enforcement agencies (399). It is also interesting to note that by the same token, authorities often make no distinction between illegal immigrant workers and political refugees (399). These facts further provide proof of the existence of an endemic seam of xenophobia that runs through the Malaysian ethnic consciousness. Whether the government is driving public xenophobia as a means to rally support and distract the public from their own short-comings, or whether it is merely reacting to the xenophobia of individual citizens is still a tenuous, chicken-and-egg issue. It does, however, still imply that ethnic schisms and xenophobic attitudes towards 'the Other' are not just colonial vestiges.

In sum then, Multiethnic Malaysia: Past, Present and Future is a thoughtprovoking and intellectually stimulating and necessary book. As mentioned earlier, several of the articles do not necessarily find common ground as per the causes and effects of history's various happenings on Malaysian interethnic relations today. As a whole however, the various issues that are pointed out in some of the contributions do emphasise or explain arguments that are made in other pieces. This interconnecting thematic strength is what makes the book a stimulating read, apart from the disagreements between the pieces giving rise to a kind of lively asynchronous debate. Multiethnic Malaysia should therefore be in the libraries and on the shelves of all those who are interested in finding solutions for contemporary Malaysia.

\title{
Muhammad Mumtaz Ali - Critical Thinking: An Islamic Perspective
}

(Batu Caves [Malaysia]: Thinkers Library, 2008). xv+169 pp.

ISBN 978-967-69-0726-4. MYR 25.00

\section{Abdul Karim Abdullah (Leslie Terebessy) International Institute of Advanced Islamic Studies}

This book explores 'critical thinking' within the context of the Islamic revivalist movement. At 169 pages, the book consists of an Introduction and five chapters. Upon closer inspection, however, the book turns out to be more of a critique of 'modernist', 'moderate', and 'liberalist' Muslims than an inquiry into the meaning of critical thinking from a purely Islamic perspective:

Today we observe a large number of Muslim scholars and intellectuals who do not hesitate to call themselves modernist, progressive, liberalist, moderate Muslims or flag-bearers of civilisational Islam. They advocate the compatibility of modernity and Islam. (x) (emphasis added)

It appears that - to Ali - Islam and modernity are simply incompatible (42). Modernisation and Westernisation to him are two sides of the same coin. The fact that large numbers of Muslims have successfully integrated in Western societies seems to have little significance to him. By 'modernity' Ali means 'secular ideologies' 
(117). However, secularism has been in existence long before the emergence of 'secular' ideologies. Indeed, it might be argued, secularism is as old as humanity. All those who rejected the 'signs of God' were considered 'secular' in the sense that they believed only in this life. They did not believe in the afterlife and were thus 'secular'.

A somewhat better way to define 'modernity', however, would be to see it as the emergence of new scientific and technological developments that are fundamentally altering how we live, conceive of ourselves and our environment, and how we relate to others. Unlike secularism, new technologies such as television or the internetmade possible by scientific discoveries - are unprecedented in human history. The new technologies, as well as developments such as globalisation, are just some examples of the 'modern' environment that is impacting daily life.

What Ali does not see - or perhaps refuses to see - is that there need not be a conflict between modernity and Islam anymore than there need be a conflict between a Muslim and his cell phone. The difference between the modern Muslim and his predecessors is that he is better connected to the rest of the world than his forefathers. Muslims are not forced to choose between Islam and modernity. They are required to adapt to it. One can adapt to modernity without adopting its negative features such as religious and moral rootlessness. One need not give up the utilisation of modern science and technology in order to be a good Muslim. In fact, one can utilise modern communication technologies in the service of Islam. Ali disapproves of 'modern' and 'liberal' thinkers, stating that the "liberal, moderate, and modernist interpretations have contributed more harm than benefit to the Muslim communities" (82):

And they teach and propagate the same thinking and thought to Muslim youths in the universities of the Muslim world. Every year, thousands of young Muslims graduate from universities with this modern and liberal thinking. $(\mathrm{x})$ (emphasis added)

The modernists and liberals supposedly "champion the implementation of Western educational models with all the associated crap such as coeducation, free mixing of sexes and abolition of Muslim dress code" (21). They "blindly follow the norms and values of Western culture" (21). "They advocate ijtihād without following [the] Islamic framework. For them, anybody can do ijtihād." They "are fully supported, promoted, and encouraged by the Western powers" (21) (emphasis added). Western education is "based on secularization of knowledge" $(48,114)$. "[M]odern Western education [...] has destroyed the confidence of Muslims in the practicability of Islam and paved the way for 'mental colonization', in which Muslims are led to 'demean' and 'disparage' themselves and their culture and traditions" (115). Etc. etc....

Ali rejects what he sees as an attempt to "replace tradition with reason" (78). He calls on Muslims to be proud of who they are. "No community and no individual can prosper, or even exist and survive, after having lost confidence in and connection 
with their own civilization" (xii). The remedy for the predicament of the Muslims is "the revival of the Islamic educational system", as exemplified in the establishment of Islamic universities (xii).

Chapter One, "Critical Thinking: Conventional Conceptions", lists several definitions of critical thinking. Ali rejects these (conventional) definitions of critical thinking because they "failed to solve the problems of mankind" and because of "their emphasis on conjecture instead of knowledge" (12). In Chapter Two, "The Islamic Revivalist Framework for Critical Thinking”, we read:

From the Islamic revivalist point of view, critical thinking must be with the purpose of seeking truth in each and every matter, and from the very beginning it must be based on the Divine guidance provided in the Qur'ān and the Sunnah (the primary normative sources of Islam) regarding right and wrong. If it does not fulfil this criterion, then it cannot be regarded as being valid from the Islamic revivalist perspective. (17)

In Chapter Three, entitled "Obstacles to Islamic Revivalist Critical Thinking”, Ali again 'identifies' modern Western education, and secular models of development, as major obstacles to the revival of the ummah: "An objective analysis of the 'adoption' and 'borrowing' reveals the fact [that the] adoption of Western models caused further degeneration of the Ummah" and "the secular models of modernisation and development have totally corrupted society" (119). According to Ali, "the real cause of failure lies in the blind following of the modern Western mind" (77). His 'observations' "confirm the truth that the liberal and modern intellectuals and leaders are responsible for the deplorable conditions of Muslim peoples" (92).

In Chapter 4, "The Methodology of Islamic Revivalist Thinking", Ali presents ijtihā $d^{1}$ as Islamic critical thinking par excellence:

An instrument in Islam known as ijtihād has been used to think and to confirm the truth or validity of any thing or idea. It had been used since the time of Prophet Muhammad, peace be upon him [...]. However, this method has not been extended outside the real of 'hukm' [ruling] or Shari'ah jurisprudence and, thus, it has stagnated. The methodology of Islamic critical thinking is that of ijtihād [...]. (75)

The decline of ijtihād resulted from "a grossroot [sic!] misunderstanding of a tradition known as the tradition of Mu'adh ibn Jabal" (83). He did not confine ijtihād to arriving at legal solutions only, but also applied it to "educational, economic, scientific and technological issues" (85). The misunderstanding of this tradition caused much harm to the Muslims by limiting the use of reason exclusively to the field of jurisprudence. In consequence, other areas of learning, where ijtihād should have been fully utilised, stagnated.

In Chapter Five, "The Islamic Revivalist Perspective of Development: A Model of Critical and Creative Thinking", Ali says: "In our view, borrowing and learning 
are not the true means and methods of knowledge" (96). But what is wrong, one may ask, with 'learning' as a method of gaining knowledge? Indeed, how can anyone obtain knowledge, if not through learning? It appears that Ali wants the Muslims to re-invent the wheel. Only then will the wheel be 'truly' Islamic. But just how practical is such advice? Any technological invention can be used for good and evil. It is up to the user to ensure that it is used for good ends and not for evil ones. It is how we use technology that is either consistent with the teaching of Islam or not. Elsewhere he says: "[U]nless the Muslim community gets rid of the slavish mentality and creates its own knowledge, there is no possibility of development" (emphasis added) (98). But is knowledge something 'created'? Or is it something discovered, as in the case of the modern knowledge, or revealed, as in the case of divine knowledge?

Ali calls for the establishment of Islamic states: "If the Muslims [...] establish Islamic states they will be successful, otherwise their fate is sealed. They will remain backward and underdeveloped" (112). The establishment of Islamic states requires a return to the caliphate: "the establishment of the institution of the Caliph and the Caliphate in a time-space context seems to be one of the biggest challenges before the Muslims" (109).

He calls for cultural purity: "Muslims should eliminate all effects of alien culture and forces through a process of fundamental reform in all arenas of life, including foreign modes of analysis and thought, attitudes, fashions and styles" (121). Elsewhere (144) he asserts: "The highest stage of man's ethical advancement is reached when he becomes absolutely free from fear and grief" (emphasis added). With such emphasis on freedom, Ali begins to sound as some of those very 'liberals' he condemns in other parts of his book.

In the main, the book exasperates rather than enlightens. Critical Thinking: An Islamic Perspective is more a polemic against 'liberals' and 'modernists' than an in-depth discussion of Islamic critical thinking. Those with an interest in a superficial and self-comforting critique of 'liberals' and 'modernists' may find the book interesting. Those looking for a focused inquiry into Islamic critical thinking, however, may be disappointed. An analysis of Islamic critical thinking is not quite the same as a critique of modernists and liberals from an Islamist perspective. The book, however, is somewhat 'revealing' in terms of the mindset of contemporary Islamists and extremists and as such can be useful when thinking of developing counterstrategies.

\section{Note}

1. A technical term of Islamic law (fiqh) that describes the process of making a legal decision by independent interpretation of the legal sources, i.e. the Qur'ān and the Sunnah. The opposite of ijtihād is taqlid ('imitation'). 